〔農化 第 43 巻, 第 10 号, p. 712 719, 1969]

$$
\begin{gathered}
\text { 牛乳のスフィンゴミエリン* } \\
\text { 藤野安彦, 山吹佐和子**, 伊藤精亮, 根岸 孝 } \\
\text { (帯质畜産大学農産化学科) }
\end{gathered}
$$

昭和 44 年 4 月 19 日受理

\title{
Sphingomyelin in Cow's Milk
}

By Yasuhiko FujIno, Sawako Yamabuki, Seisuke ITo and Takashi NEgISHI

Department of Agricultural Chemistry, Obihiro Zootechnical University

Bovine milkfats contain about $1 \%$ phospholipids, of which sphingomyelin, $\mathrm{N}$-acylsphingosylphosphorylcholine, is one of the representatives in quantity together with lecithin and cephalin. The present paper describes composition of the constituents of the long chain acid as well as the long chain base in sphingomyelin purely isolated from cow's milk. As the component fatty acids, nineteen ones were found between the range of $C_{12}$ and $\mathrm{C}_{24}$. The greater part of them belonged to the long chain saturated acids, among which $C_{23: 0}, C_{22: 0}, C_{24: 0}$ and $C_{16: 6}$ were predominant in decreasing order. As the component long chain bases, seven kinds, namely, $C_{18}$-sphingosine, $C_{16}$-sphingosine, 16-methyl- $\mathrm{C}_{17}$ sphingosine, $\mathrm{C}_{16}$-dihydrosphingosine, $\mathrm{C}_{17}$-sphingosine, $\mathrm{C}_{18}$-dihydrosphingosine and probably 17-methyl- $\mathrm{C}_{18}$-sphingosine were detected in decreasing sequence. The dominating bases were $\mathrm{C}_{18}$-sphingosine and $\mathrm{C}_{16}$-sphingosine.

(Received April 19, 1969)

\section{鍺 言}

牛乳は約 3.3\% の脂質を含むが，この中のほぼ $1 \%$ を 占める複合脂質は，乳脂肪球の構成分として重要な役割 をはたし，また乳および乳製品のフレーパーの生成に関 連があるとされている．複合脂質には，リン脂質と糖脂 質があるが，牛乳中に糖脂質は少なく，複合脂質の大部 分はレシチン、タファリン,スフィンゴミエリンを主成分 とするリン脂質である(2).このうち、レシチンとケフォ リンについては散から知られていたが，スフィンゴミェ リンについては近年までその存在さ交明らかでなく( ${ }^{(3)}$, 夷娩技術の進歩によってこのごろようやく分離，定量， 分析に関する研究が行なわれる上らになってきたのが実 状である.スフィンゴミエリンは，脂肪酸，スフィンゴ シン程基, リン酸就よびュリンを成分とし， N-アシル スフィンゴシルホスホリルコリンの構造を有する一種の リン脂質であるが, 従来, 牛乳スフィンゴミエリンの研

* 本研究の要旨恃日本畜産学会第 55 回大会（昭和 43 年 8 月 31 日〜9月1日，帯広）で講演した。また， その一部は日本畜産学会報(1)に笔表した。

*** 現在, 文化女子大学室䉒短期大学
究の多くはその定量ないし脂肪酸組成に向けられていて， その長鎖虽基の組成については全く調べられていなかっ た.われわれは牛乳からスフィンゴミエリンを純粋に分 離し，その脂肪酸組成を従来の文献と対比して調べると ともにこれまで未知であったスフィンゴシン塩基の組 成を明らかにしたので報告する。

\section{実 験 方 法}

1. スフィンゴミエリンの分離 ホルスタイン種の 牛乳 $12 l$ に\% トリタロル酢酸を加えて脂質を乳タン パクとともに沈殿させた後, 沈殿部分を水洗し凍結乾燥 した. 約 $700 \mathrm{~g}$ の乾燥粉末に 3 倍量のクロロホルムーメ タノール(2:1) を加えて全脂質を抽出し，抽出液を隇 圧濃縮した㣪アセトン処理して約 $10 \mathrm{~g}$ の白色粉末の複 合脂質画分を得た。これを次のようなケイ酸カラムク ロマトグラフィーに供して精製した，すな⿰力口゙，ケイ酸 (Mallinckrodt, $100 \mathrm{mesh}$ )ーセライト (2:1) $75 \mathrm{~g}$ を直 佳 $2 \mathrm{~cm}$, 長さ $70 \mathrm{~cm}$ のカラムに充填し, 試料をク口足 ホルム $1000 \mathrm{ml}$, アセトン $500 \mathrm{ml}$, クロロホルムーメタ ノール (4:1) $500 \mathrm{ml}$, 同 $(3: 2) 500 \mathrm{ml}$, 同 $(1: 1)$ $750 \mathrm{ml}$, 同 $(1: 4) 500 \mathrm{ml}$, メタノール $500 \mathrm{ml}$ で順次 


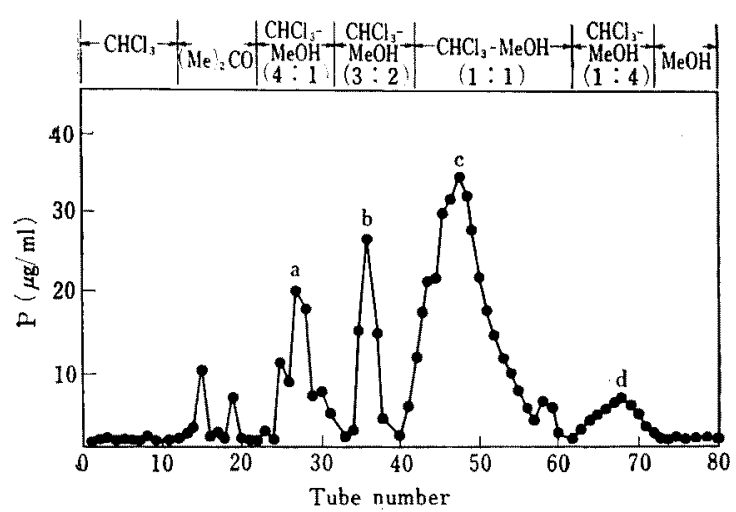

Fig. 1. Silicic Acid Column Chromatogram of the Complex Lipids from Milk.
a : cephalin
b : phosphatidyl choline
c : sphingomyelin
d : lysophosphatidyl choline

に溶出させた。溶出液を $50 \mathrm{ml}$ ずつ分取し，それぞれの リンを測定 ${ }^{(5)} し て$ 得た曲線を Fig. 1 に示す. 薄層ク マトグラフィーにより，Fig. 1 の主ピーク，a,b,c,d は それぞれケファリン，レシチン，スフィンゴミエリン， リゾレシチンに該当することが認められた。このうらス フィンゴミエリンのフラクションを集め, Dawson 法 ${ }^{(6)}$ によりアルカリ加水分解を行なって混在する少量のグリ セロリン脂䁈を除去した後，再びクロロホルムーメ夕， 一ルを溶出溶媒とする上述のケイ酸カラムクロマトグラ フィ一に供し，溶出物をエーテルから再結して純スフィ ンゴミェリンの白色結晶状粉末 $300 \mathrm{mg}$ を得大。

\section{2. スフィンゴミエリンの加水分解}

a) 脂肪酸画分の調製：スフィンゴミェリン10 mg 飞 $5 \%$ ×タノール性硫酸 $5 \mathrm{ml}$ を加觉, $100^{\circ} \mathrm{C} て ゙ 6$ 時間, 水浴上で還流加熱，椧却後 $5 \mathrm{ml}$ ずつの石油エーテルで 3 回抽出し，抽出液を $5 \mathrm{ml}$ ずつの水で 3 回水洗後，䒜 水硫酸ソーダで脱水して石油エーテルを減王濃縮，脂肪 酸のメチルェステル $3.7 \mathrm{mg}$ を得た。

b）スフィンコシシン塩基画分の調製：Gaver, Sweely の方法(7)により行なった. スフィンゴミェリン 10 $\mathrm{mg}$ に $1 \mathrm{~N}$ 含水メタノ一ル性塩酸 $5 \mathrm{ml}$ を加え, $70^{\circ} \mathrm{C}$ て 18 時間水浴上で器流加熱，冷却後 $5 \mathrm{ml}$ ずつの石油エー テルで 3 回抽出して脂倣酸メチルエステルを除去. 残淮 を濃カセイカリ溶液で $\mathrm{pH} 9.5$ に調整, $5 \mathrm{ml}$ ずつのエー テルで 3 回抽出，エーテル層を水洗，無水硫酸ソーダで
脱水した後エーテルを娍压濃縮して粗スフィンゴシン画 分を得た。これをヶイ酸 $1 \mathrm{~g}$ のカラムに供し， $15 \mathrm{ml}$ クロロホルムで溶出させて少量の脂肪酸メチルェステル を除去, ついで $15 \mathrm{ml}$ のタノールで溶出させ，メタ， ール溶液を減王濃縮, スフィンゴシン塩基 $3 \mathrm{mg}$ を得 t.

\section{3. スフィンコシン塩基誘導体の調製}

a) ジニトロフェニル (DNP) 化：Karlsson の力 法 $^{(8)}$ により次のよらにしてスフィンゴシン塩基の DNP誘導体を調製した、スフィンゴシン熄基 $3 \mathrm{mg}$ K $2 \mu \mathrm{l}$ の フロロ ジニトロベンゼン含有のエチルアルコール $1 \mathrm{ml}$ と，ホウ酸カリウム緩衝液 $(\mathrm{pH} \mathrm{10)} 4 \mathrm{ml}$ を加之, 30 分 間 $60^{\circ} \mathrm{C}$ K保つ. 冷却後 $5 \mathrm{ml}$ ずつのエーテルで 3 回抽 出, エーテル層を減王濃縮 してスフィンゴシン塩基の DNP-誘導体を得た。

b) トリメチルシリル (TMS) 化 : Carter, Gaver の方法 ${ }^{(9)}$ に從いスフィンゴシン塩基 $1 \mathrm{mg}$ にシラン試薬 (ピリジンーへキサメチルジシラザンートリメチルクロル シラン $(10: 13: 8)$ ) をスフィンゴシン程基が $1 \%$ 含ま 机るように加党て長鎖塩基のトリメチルシリル誘導体を 調製した。

c）過ヨウ素酸酸化： Gatt, Rapport の方法 ${ }^{(10)}$ に集 じまずスフィンゴシン塩基を還元して飽和のスフィン ゴシン塩基を調製し，つで Sweely，Moscatelli の方 法(11)に従いこれの過ヨウ素酸酸化を行なった。スフィ

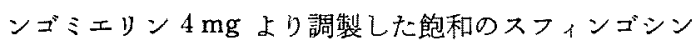
約 $1.5 \mathrm{mg}$ を $0.3 \mathrm{ml}$ のメタノールに溶解, 1/5 倍量の $0.2 \mathrm{M}$ ×夕過ヨウ续酸ソーダを加之, 暗所で 60 分間室 温に放犆する。ついて 2 倍量の塩化メチレンと半昜の水 を混和して遠心分離した，上層はさらに 2 倍量の塩化メ チレンで抽出し，下檿の塩化メチレン層を合一して滤渦 後，真空乾燥した．生成した脂肪性粗アルデヒドはタイ 酸 $2 \mathrm{~g}$ を充填したカラムに供し，15 $\mathrm{ml}$ のクロロホルム で溶出させ，絰素気流下にクロロホルムを除いて試料と Lt

d）脂肪性アルデヒトの還元（アルコール化）：過 ヨウ素酸酸化で得られた脂肪性アルデヒドをCarter,

Hirschberg の力法 ${ }^{(12)}$ に捝い脂䏳性アルュールに還元し た.スフィンゴミェリン $4 \mathrm{mg}$ より調製した脂肪性アル デヒドを $0.5 \mathrm{ml}$ のメタノールに浴解させ, $0.5 \mathrm{ml}$ の水 素化ホウ素ナトリウム溶液を加え 30 分間室温に放固す る. ついで $0.03 \mathrm{ml} の 1 \mathrm{~N}$ 篮酸, $0.5 \mathrm{ml}$ の水, $0.3 \mathrm{ml}$ 
のメタノール, $1.6 \mathrm{ml}$ のクロロホルムを混和し遠心分

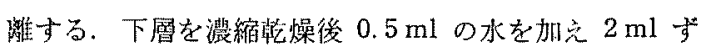
つのエーテルで 3 回抽出, エーテルを除去して脂肪性ア ルコールを得た。これにシラン試薬(乹を加え，脂肪性ア ルコールのトリメチルシリル誘道体を調製した。

4. ガスクロマトグラフィー 柳本 GCG-5 DH 型 （氷泰イオン化検出器）ガスクロマトグラフを用いて各 成分の分析を行なった，脂肪酸メチルエステルに対する 運真条件は Table II に，TMS-スフィンゴシン程基に 対する運転条件は Fig. 5 に，過引ウ菜酸酸化物に対する 運転条件は Fig. 6 に，また脂肪性アルコールの TMS誘導体に対する運転条件は Fig.7 にそれぞれ示した。

5. 標準品 スフィンゴミエリンは Fujino, Negishi(19) が馬脊时道がら調製したもの，脂肪酸は访販の結晶 ラウリン酸，ミリスチン酸，パルミチン酸拈よびステア リン酸， $C_{18}$ スフィンゴシンは牛脾缄のセラミドから調 製したもの ${ }^{(14)}, C_{18}$ ジヒドロスフィンゴシンは藤野(15) の調製したジヒドロフレノシンをアルカリ加水分解した もの，テトラデカナールとへキサデカナールは札㨪医科 大学の大野教授から患与されたもの、テトラデカノール とへキサデカノールは該当のア゙ルデヒドを還元して調製 したものをそれぞれ標隻品として用いた。

結 果

1. スフィンゴミエリンの純度

a) 薄層クロマトグラフィー 牛靾より分蜼精製し

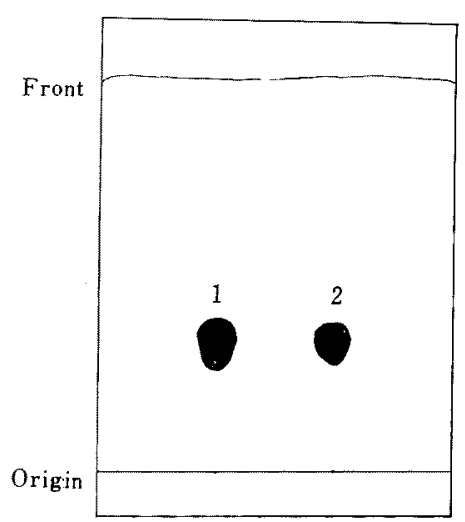

Fig. 2. Thin-layer Chromatogram of Sphingomyelin from Cow's Milk.

Coating material : silica gel G

Solvent system : chloroform-methanol-water $(65: 25: 4)$

Detection : iodine vapor, Dragendorff reagent

1. sphingomyelin from cow's milk

2. standard sphingomyelin(13)
たスフィンゴミェリンの薄層クロマトグラムを Fig. 2 に示した。スフィンゴミェリンはプレート上でただ一つ のスポットを与光，Rf 值は標準スフィンゴミェリン(13) のそれに完全に一致した。

b) スフィンコミエリンの分析 スフィンゴミェy ンの分析絬果を Table I K示す. リンは King 法(5), 空素はミクロケルダール法，スフィンゴシンは Lauter, Trams 法(16)，遊陮コリンは Glick 法(17)でをれぞれ睍 定した，各湘定值は計算值とほぼ一致し，リン：咥素： スフィンゴシン:遊睢コリンの比はほとえど 1:2:1： 1 に等しかった。

Table I. Analytical Data_of Sphingomyelin from Cow's Milk

\begin{tabular}{ccc}
\hline & Found & $\begin{array}{c}\text { Calcd. for N-arachidyl- } \\
\text { sphingosyl-phosphory1- } \\
\text { choline } \mathrm{C}_{43} \mathrm{H}_{89} \mathrm{O}_{7} \mathrm{~N}_{2} \mathrm{P}\end{array}$ \\
\hline $\mathrm{P}$ & $3.47 \%$ & $3.99 \%$ \\
$\mathrm{~N}$ & $3.14 \%$ & $3.61 \%$ \\
Sphingosine & $38.40 \%$ & $38.53 \%$ \\
Free choline & $14.00 \%$ & $15.59 \%$ \\
$\mathrm{P}: \mathrm{N}:$ & Sphingosine : & $1: 2.01:$ \\
Choline & $1.15: 1.03$ & $1: 2.0: 1.0: 1.0$ \\
Melting point & $199^{\circ} \mathrm{C}$ & $197 \sim 198^{\circ} \mathrm{C}(13)$ \\
\hline
\end{tabular}

c) スフィンゴミエリンの赤外線吸収スペクトル スフィンゴミェリン $3 \mathrm{mg}$ を臭化カリウムと混合して錠 剤とし，日本分光工策 IR-S 型を用いて测定した赤外 線吸取スペクトルを Fig. 3 に示す. $1650 \mathrm{~cm}^{-1}$ と 1540 $\mathrm{cm}^{-1}$ 付近に酸アミドの，1087 1064 $\mathrm{cm}^{-1}$ のところに リン酸の，および $970 \mathrm{~cm}^{-1}$ にトランス二重結合の深い 吸収がスフィンゴミェリンK特徴的なピークとして認め られ，グリセロリン脂質の夾雑にもとづくエステル結合 の吸収 $\left(1739 \mathrm{~cm}^{-1}\right)$ は認如らなかっった。 このスペクト ルのデータは, 標準スフィンゴミエリン(13)のそれに完全 に一致した。

\section{2. 構成脂肪酸}

スフィンゴミエリンの加水分解で得られた脂肪酸メチ ルエステルをガスクロマトグラフィーに供し，そのチャ 一トから同定した脂助酸とその組成を Table II に示寸. 表のように $C_{12}$ から $C_{24}$ までの 19 種類の脂肪酸が検出 された。 その主成分は多い万から $\mathrm{C}_{29: 0,} \mathrm{C}_{22: 0}, \mathrm{C}_{24: 0}, \mathrm{C}_{16: 0}$ で，この 4 つで全脂肪酸の $75 \%$ 以上に達した，飽和脂 肪酸が $90 \%$ 以上を占め，不飽和脂肪酸は少量，低級脂 肪酸は全く認められなかった。 


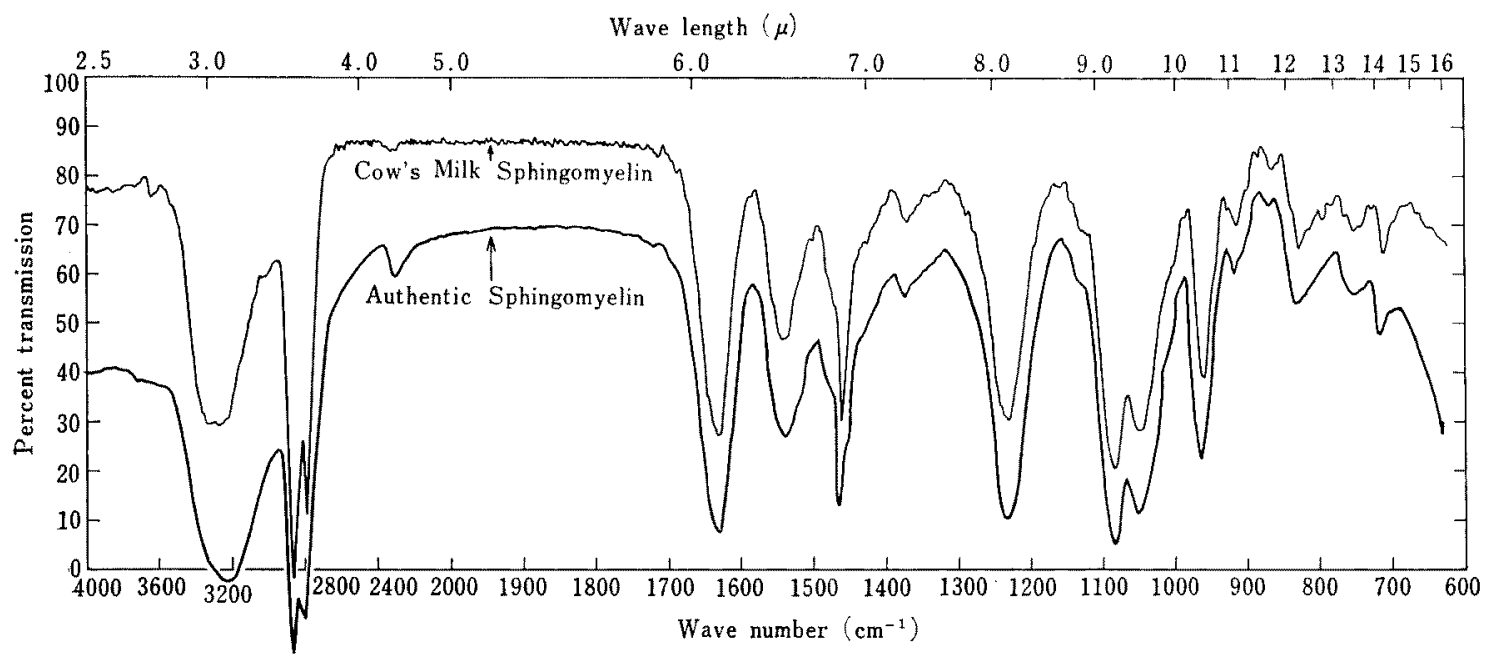

Fig. 3. Infrared Spectrum of Sphingomyelin from Cow's Milk.

( $3 \mathrm{mg}$ of sample was packed in $\mathrm{KBr}$.)

Table II. Fatty Acid Composition of Sphingomyelin from Cow's Milk

Operative conditions of gas chromatogram : Column $0.3 \times 150 \mathrm{~cm}$ with $15 \%$-succinate polyester $(60 \sim 80 \mathrm{mesh})$, column temp. $180^{\circ} \mathrm{C}$, injection temp. $255^{\circ} \mathrm{C}, \mathrm{N}_{2} 45 \mathrm{ml} / \mathrm{min}, \mathrm{H}_{2} 30$ $\mathrm{ml} / \mathrm{min}$, air $800 \mathrm{ml} / \mathrm{min}$, sensitivity $10^{9}$, attenuator $1 / 1$ and chart drive $2 \mathrm{~cm} / \mathrm{min}$.

\begin{tabular}{rrrrr}
\hline Fatty acid & Authors & $\begin{array}{c}\text { Morrison, } \\
\text { Jack \& } \\
\text { Smith(19) }\end{array}$ & Badings(20) & $\begin{array}{c}\text { 㮏, 土肥, } \\
\text { 三野(22) }\end{array}$ \\
\hline $12: 0$ & 3.0 & 0.3 & 0.9 & 0.5 \\
$13: 0$ & 2.6 & tr. & - & - \\
$14: 0$ & 7.1 & 2.5 & 9.5 & 1.4 \\
$15: 0$ & 2.9 & 0.4 & - & - \\
$15: 1$ & 1.3 & - & - & - \\
$16: 0$ & 11.8 & 22.1 & 30.5 & 20.7 \\
$16: 1$ & 0.4 & 0.8 & 0.7 & 1.1 \\
$17: 0$ & 0.6 & 0.6 & - & - \\
$17: 1$ & 0.1 & $t r$. & - & - \\
$18: 0$ & 1.6 & 4.5 & 6.3 & 2.3 \\
$18: 1$ & 0.3 & 5.0 & 9.6 & 0.8 \\
$18: 2$ & 0.3 & 0.9 & 1.2 & 0.5 \\
$20: 0$ & 1.1 & 0.6 & 0.6 & 2.4 \\
$21: 0$ & 1.1 & 0.8 & - & - \\
$22: 0$ & 19.6 & 14.7 & 8.5 & 13.1 \\
$23: 0$ & 27.0 & 27.0 & 13.1 & 25.2 \\
$24: 0$ & 18.4 & 14.8 & 8.2 & 19.8 \\
$24: 1$ & 0.5 & 1.9 & 2.2 & 12.0 \\
\hline
\end{tabular}

3. 構成スフィンゴシン塩基

a) DNP-誘導体の薄層クロマトグラフィー スフ インゴミェリンの水解とDNP-化で得られた DNPースフ ィンゴシン熄基を Michalec の方法 ${ }^{(18)}$ に準じて二次元薄

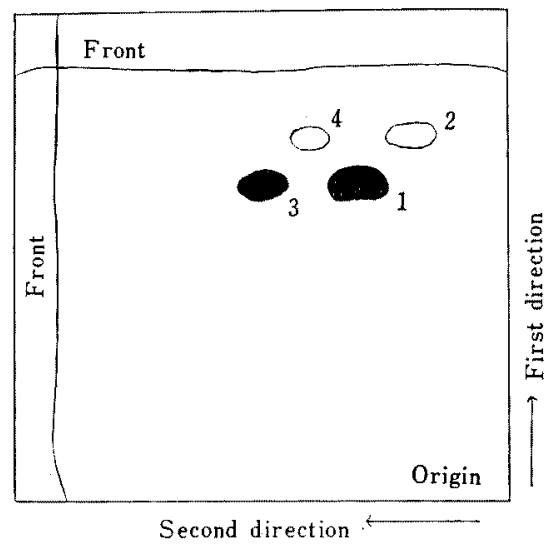

Fig. 4. Two-dimensional Thin-layer Chromatogram of DNP-sphingosine Bases obtained from Cow's Milk Sphingomyelin.

Coating material : aluminium oxide $\mathrm{G}$

Solvent system : 1 st development, chloroform-methanol (98:2); 2 nd development, methanol-trimethylamine-water $(85: 5: 10)$ saturated with tetralin; between 1 st and 2 nd development plate was impregnated by $5 \%$ tetralin in ether.

1. $\mathrm{C}_{18}$-sphingosine (?)

2. 3-O-methyl $\mathrm{C}_{18}$-sphingosine (?)

3. $\mathrm{C}_{16}$-sphingosine (?)

4. 3-O-methyl $\mathrm{C}_{16}$-sphingosine (?)

層クロマトグラフィ一に供した。陚料をアルミニウムー オキサイドGのプレートに着点した後，まずクロロホル ムーメタノール (98:2) で一次展開, ついでェーテル性 $5 \%$ テトラリン溶液に含浸し, ニーテルを冡発させた 
後, テトラリン飽和のメタノールートリタチルアミンー水 (85:5:10) で二次展開を行なった。紫外光下で検出さ れたスフィンゴシンの DNP-誘導体の三次元薄層クロマ トグラム孛 Fig. 4 に示す。４つのスポットの5ち2つ はそれぞれ標準の $\mathrm{C}_{18}, \mathrm{C}_{16}$ スフィンゴシンとほぼ一致し たが，各スポット内に濃淡があり，それぞれ複数のスフ ィンゴシン塩基から成ることが子測された。㚣との2つ のスボットはスフィンゴミエリンを酸で分解したとき生 した3-O-メチル-C $18^{-ス フ ィ ン コ ゙ シ ン, ~ 3-0-メ チ ル-C ~}$ スフィンゴシンと推定されたが確諗できなかった。

b) TMS-誘導体のガスクロマトクラフィー スフ ィンゴシン塩基の鍾類をもっと謭しく分析するために， 牛乳スフィンゴミエリンの水解と TMS 化で得られた TMS-スフィンゴシン塩基をがスクロマトグラフィーに 供した成績在 Fig. 5 に正す．スフィンゴシン塩基の同 定は， $C_{18}$ スフィンゴシンと $C_{18}$-ジヒドロスフィンゴシ ンについては，乙れぞれ標準品 ${ }^{(14,15)}$ と比較して行ない， その他の長鎖塩基については，それぞれの保持時間を片 刘数表にブロットして，それらが直線関係になること

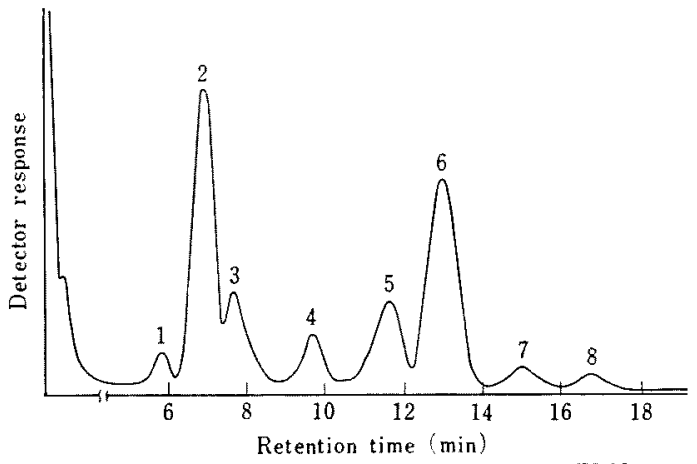

Fig. 5. Gas-Liquid Chromatogram of TMSsphingosine Bases obtained from Cow's Milk Sphingomyelin.

Operative conditions: column $0.3 \times 180 \mathrm{~cm}$ with $5 \% \quad \mathrm{SE}-30 \quad(60 \sim 80 \mathrm{mesh})$, column temp. $210^{\circ} \mathrm{C}$, injection temp. $280^{\circ} \mathrm{C}, \mathrm{N}_{2} 40$ $\mathrm{ml} / \mathrm{min}, \quad \mathrm{H}_{2} 30 \mathrm{ml} / \mathrm{min}$, air $800 \mathrm{ml} / \mathrm{min}$, Sensitivity $10^{9}$, attenuator $1 / 1$ and chart drive $2 \mathrm{~cm} / \mathrm{min}$.

1. 3-O-methyl- $\mathrm{C}_{16}$-sphingosine

2. $\mathrm{C}_{10}$-sphingosine

3. $\mathrm{C}_{16}$-dihydrosphingosine

4. $\mathrm{C}_{17}$-sphingosine

5. 3-O-methyl- $\mathrm{C}_{18}$-sphingosine and/or 16 methyl- $\mathrm{C}_{17}$-sphingosine

6. $\mathrm{C}_{18}$-sphingosine

7. $\mathrm{C}_{18}$-dihydrosphingosine

8. 17-methyl- $\mathrm{C}_{18}$-sphingosine (?)
を確認した上で Carter, Hirschberg ${ }^{(12)}$ の Equivalent Chain Length (以下 ECL と略称) と比較した．との結 果，見出された 8 つの゚ークは，保持時間の低い方から， 3-O-メチル-C $\mathrm{C}_{16}$-スフィンゴシン $(2.6 \%), \mathrm{C}_{16}$-スフィン ゴシン $(23.5 \%), C_{16}$-ジとドロスフィンゴシン $(9.8 \%)$. $\mathrm{C}_{17}$ スフィンゴシン $(7.9 \%), 3-0-x チ ル-C_{18}$ スフィン ゴシンおよび/または16-メチルーC 1 17ースフィンゴシン

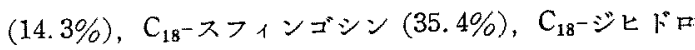
スフィンゴシン $(3.8 \%), 17-x チ ル-C_{18}$ スフィゴシン (2.7\%)（?）上同定された.このらち，3-0-メチルース フィンゴンンは酸水解による人士産物である.3ー0-メチ ルーC $\mathrm{C}_{18}$ ースフィンゴシン(ECL 17.10) と16-メチル-C 1 17 ス フィンゴシン (ECL 17.28)はほほ同じ保持時間を有する ので,ガスクロマトグラム上では，一つのピークとして 乩和れている. Fig.5の5のピーク中に3-0-メチル $\mathrm{C}_{18}$ ースフィンゴシンが含有されるとすると，その割合は。 $\mathrm{C}_{16}$-スフィンゴシンと 3-O-メチル-C $\mathrm{C}_{16}$-スフィンゴシン との比率から類推して約 3.6\%，したがって，16-メチ ルーC $\mathrm{C}_{17}$ スフィンゴシンは，10.7\% と計算される。

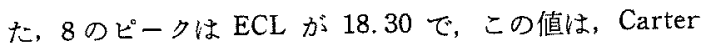

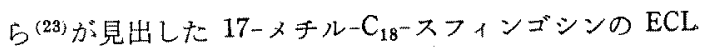
(18.28) とほぼ一致した. 全体を通じ，主ピークは， $\mathrm{C}_{18}$ スフィンゴシンと $\mathrm{C}_{16}$-スフィンゴシンで両方合和せ て全塩基の $60 \%$ 近くを占めた。

c) 脂肪性アルデヒトのガスクロマトグラフィー 16-メチル-C 17 -スフィンゴシンの存在の有無を検討する ことを主眼として，牛乳スフィンゴミエリンの水解と水 添後の過ヨウ素酸酸化で得られた脂肪性アルデヒドをガ スクロマトグラフィーに供した成績を Fig. 6 に示す. アルデヒドの同定は，テトラデカナールとへキサデカナ 一ルについてはそれそれの標準品と比較して行ないぺ ンタデカナールは標準アルデヒドのそれぞれの保持時間 をプロットした片詨数グラフ上より求めた. その結果, ガスクロマトグラムに表われた 4 つの明らかなピークは 保持時間の短い方からテトラデカナール $\left(33.4 \% ; \mathrm{C}_{16}{ }^{-}\right.$ スフィンゴシン拈び $C_{16}$ ジヒドロスフィンゴシンに由 来), ペンタデカナール $\left(10.4 \% ; \mathrm{C}_{17}\right.$ スフィンゴシンK 由来)，14-メチル-ペンタデカナール $(11.3 \% ; 16$ メチ ルーC $\mathrm{C}_{17}$ スフィンゴシンに由来)（?），へキサデカナール $\left(41.8 \% ； C_{18}\right.$ スフィンゴシン拈よび $\mathrm{C}_{18}$-ジヒドロスフ ィンゴシンに由来）と同定されたこのうち，14-メチ ルーペンタデカナールの同定はやや不確実, またペンタ 


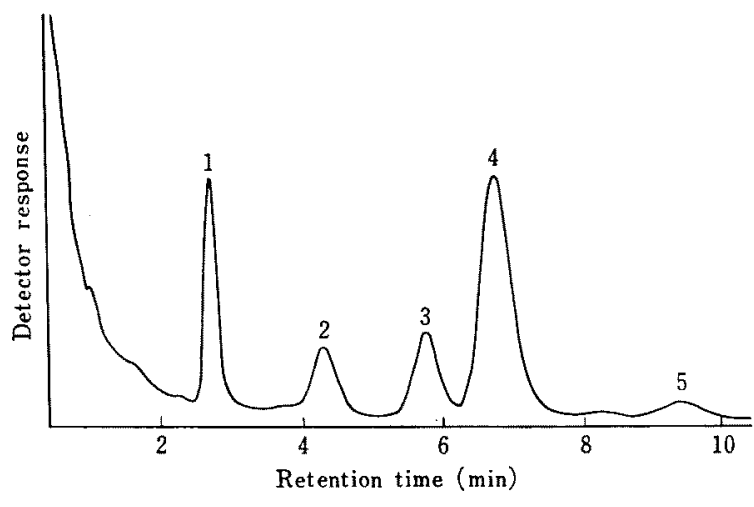

Fig. 6. Gas-Liquid Chromatogram of Fatty Aldehydes derived from Cow's Milk Sphingomyelin.

Operative conditions : column $0.3 \times 150 \mathrm{~cm}$ with $15 \%$ succinate polyester $(60 \sim 80 \mathrm{mesh})$, column temp. $150^{\circ} \mathrm{C}$, injection temp. $265^{\circ} \mathrm{C}, \mathrm{N}_{2} 45 \mathrm{ml} / \mathrm{min}$, $\mathrm{H}_{2} 30 \mathrm{ml} / \mathrm{min}$, air $800 \mathrm{ml} / \mathrm{min}$, sensitivity $10^{9}$, attenuator $1 / 1$ and chart drive $2 \mathrm{~cm} / \mathrm{min}$.

1. tetradecanal (derived from $\mathrm{C}_{16}$-sphingosine and $\mathrm{C}_{16}$-dihydrosphingosine)

2. pentadecanal(derived from $\mathrm{C}_{17}$-sphingosine)

3. 14-methyl-pentadecanal (derived from 16methyl- $\mathrm{C}_{17}$-sphingosine)

4. hexadecanal (derived from $\mathrm{C}_{18}$-sphingosine and $\mathrm{C}_{18}$-dihydrosphingosine)

5. 15-methyl-hexadecanal (derived from 17methyl- $\mathrm{C}_{18}-$ sphingosine) (?)

デカナールの前の小さなピークは同定できなかった５ のピークは, その ECL (16.75) が Carter ら (29)

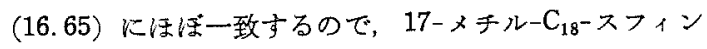
ゴシンに由来する 15-メキル-へキサデカナールと推定 された。

d）脂肪性アルコールのガスクロマトグラフィー 16-メチル-C $\mathrm{C}_{17}$-スフィンゴシンの存在を確かかるために， 牛乳スフィンゴミエリンからのスフィンゴシン塩基の過 ヨウ素酸酸化物を脂肪性アルコールに導きこれをTMS 化してガスクロマトグラフィーに供した成績を，Fig. 7 に示す.アルコールの同定は，テトラデカノールとへキ サデカノールについてはそれぞれ標準品と比較して行な い, ペンタデカノールと 14-メキルーペンタデカノールは 標準アルコールのそれぞれの保持時間をプロットした 片対数表より求め，さらに Carter, Hirschberg(12) の ECL と比較した. その結果, アルコールのガスクロマト グラムは対応するアルデヒドのそれと全く同じパターン

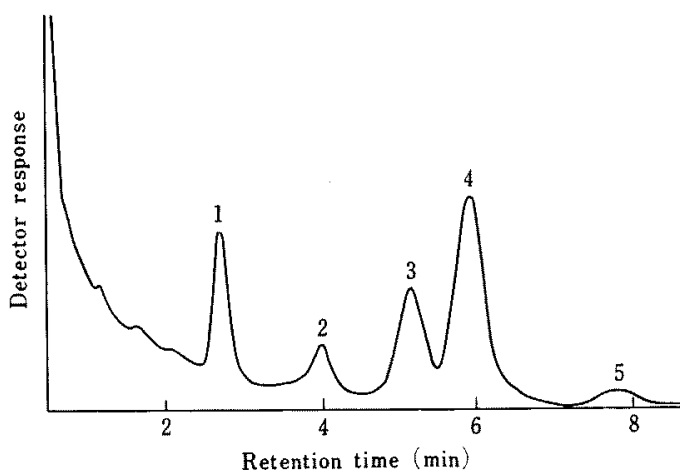

Fig. 7. Gas-Liquid Chromatogram of TMSalcohol Derived from Cow's Milk Sphingomyelin.

Operative conditions : column $0.3 \times 180 \mathrm{~cm}$ with $5 \%$ SE-30 (60 80 mesh), column temp. $180^{\circ} \mathrm{C}$, injection temp. $220^{\circ} \mathrm{C}, \mathrm{N}_{2} 40$ $\mathrm{ml} / \mathrm{min}, \quad \mathrm{H}_{2} 30 \mathrm{ml} / \mathrm{min}$, air $800 \mathrm{ml} / \mathrm{min}$, sensitivity $10^{9}$, attenuator $1 / 1$ and chart drive $2 \mathrm{~cm} / \mathrm{min}$.

1. tetradecanol (derived from $\mathrm{C}_{16}$-sphingosine and $\mathrm{C}_{16}$-dihydrosphingosine)

2. pentadecanol (derived from $\mathrm{C}_{17}$-sphingosine)

3. 14-methyl-pentadecanol (derived from 16-methyl- $\mathrm{C}_{17}$-sphingosine)

4. hexadecanol (derived from $\mathrm{C}_{18^{-}}$sphingosine and $\mathrm{C}_{18}$-dihydrosphingosine)

5. 15-methyl-hexadecanol (derived from 17 -methyl- $\mathrm{C}_{18}$-sphingosine) (?)

を示し，それぞれ，テトラデカノール（C $\mathrm{C}_{16}$ スフィンゴ シン怙よび $C_{16}$-ジヒドロスフィンゴシンに由来)，ペン タデカノール ( $\mathrm{C}_{17}$ スフィンゴシンに由来)，14-メチルー ペンタデカノール（16-メチルーC $\mathrm{C}_{17}$ ースフィンゴシンに由 来), へキサデカノール ( $\mathrm{C}_{18}$-スフィンゴシン扰よび $\mathrm{C}_{18^{-}}$ ジヒドロスフィンゴシンに由来) および15-メチルーへキ サデカノール (17-メチル-C 18 スフィンゴシンに由来) （?）とそれぞれ同定された.

牛乳は $0.03 \%$ の複合脂質を含み，そのららスフィン ゴミエリンは 19\%を占めることが報告されている(19). これによれば牛乳 $12 l$ 中には約 $700 \mathrm{mg}$ のスフィンゴ ミエリンが含まれることになるが，われわれが分離した

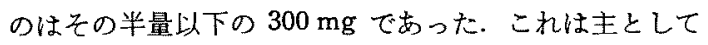
溶媒分画とヶイ酸カラムクロマトグラフィーによる精製 操作の途中で損失したものと思われる. 得られたスフィ ンゴミェリンは薄層クロマトグラム上の $R f$ 值, 分析值 
および亪外線吸収スペクトルから判断して，全く純品で 岕るとみなされる。

牛乳スフィンゴミエリンの構成脂肪酸についての分析 結果仗, Badings(20), Smith, Lowry(21), Morrison $b^{(19)}$,

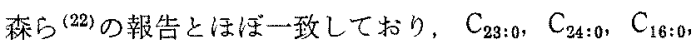
$\mathrm{C}_{22: 0}, \mathrm{C}_{20: 0}$ などの高級脂肪酸が多いこと，とくに $\mathrm{C}_{23}$ 酸 の存在することが特徽的であったこの傾向は牛乳のみ ならず，ヒト，ブタ，ラクダ，口バ，ヒッジ, スイギュ ウなどの種々の哺乳動物の乳スフィンゴミェリンにおい て豆様であるといら(24,25).

生乳スフィンゴミェリンの粠成スフィンゴンン塩基の 種類は, DNP-誘導体, TMS-誘導体, 脂肪性アルデヒド および脂肪性アルュールの4つの分析結果を総合すると， 含量の多い方から順に $\mathrm{C}_{18^{-}}$スフィン゙シン， $\mathrm{C}_{16^{-}}$スフィ ンゴシン，16-メチル-C $C_{17}$ スフィンゴシン， $C_{16}$-ジヒド ロスフィンゴシン， $C_{17}$ スフィンゴシン， $C_{18}$-ジヒドロ スフィンゴシンおよび多分 $17-x チ ル-C_{18}$ スフィンゴシ ンの7つで, このうち $C_{18}$-スフィンゴシンと $C_{16}$-スフ インゴシンは合わせて全スフィンゴシンの約 $60 \%$ に達 した，前回(1)放れわれは TMS-誘導体のガスクロマトグ ラフィーで, $C_{18}$-スフィンゴシン， $C_{16}$ スフィンゴシン の在かに，不確実ながら $C_{18}$ ジヒドロスフィンゴシン， $\mathrm{C}_{17}$ スフィンゴシン, $\mathrm{C}_{14}$ ースフィンゴシンに相当するピ 一クの存在を報じたが，このらちで $C_{14}$ に相当するスフ ィンゴシンは今回確認さ机なかった。これは㧍そらく TMS-化の途中で混入した不純物にもとつくくのと思わ 礼る。

今までに，牛乳スフィンゴミエリンのスフィンゴシン 塩基部分についての報告は全くなかったが，本研究によ り，一般の動物組織に多く見出される $\mathrm{C}_{18}$ 憩基 $\left(\mathrm{C}_{18}\right.$-ス フィンゴシンと $C_{18}$ ジヒドロスフィンゴシン) のほが， $\mathrm{C}_{16}$ 塩基 $\left(\mathrm{C}_{16}\right.$-スフィンゴシンと $\mathrm{C}_{16}$-ジとドロスフィン

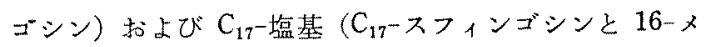
チル $-C_{17}$ スフィンゴンン) の存在することが明らかにさ

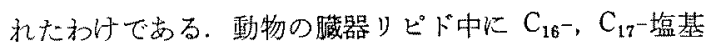
が少量ながら含まれることは近年 Michalec(26), Karlsson(27) および Carter, Hirschberg(12) によって報告さ れている、とくに，Carter, Hirschberg(12) は，ゅシ腎 蔵のスフィンジミエリン中に16-メチル-C 1 -スフィンゴ シンを見出しこれがルーメン敛生物の菌体脂質に由来 するわのか子しれないことを示唆しているが，これと同 じ分枝スフィンゴシン塩基がわれわれの牛乳スフィンゴ
ミエリン中にも認められたことはきわめて骨陎深い，ま た, Carter, Gaver ${ }^{(23)}$ は Tetrahymena Pyriformis K

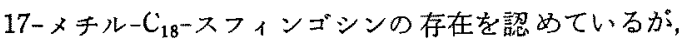
われわれるやや不確実ながらこのbのを垺のスフィン ゴミエリン中に見出した. これら各種のスフィンゴシン 程基の生成起源ないし由来の探求は，今啳に委水られた 課題の一つで女ろら.

\section{要}

\section{䄪}

（1）牛乳から純粋なスフィンゴミエリンを単離し， その脂肪酸と長鎖塩基の組成を調べた。

(2) 牛乳スフィンゴミエリンの構成脂肪酸として, $\mathrm{C}_{12}$ からら $\mathrm{C}_{24}$ までの 19 種が検出された。 その大部分は 長鎖の飽和脂肪酸で，そのらちで主なるのは多い方から 順に, $\mathrm{C}_{28: 0}, \mathrm{C}_{22: 0}, \mathrm{C}_{24: 0}, \mathrm{C}_{16: 0}$ で岕った。

(3) 牛乳スフィンゴミエリンを構成する長鎖塩基と して，多い方から順に， $C_{18}$ ースフィンゴシン， $C_{16}$-スフ インゴシン, 16-メチル-C $\mathrm{C}_{17}$ スフィンゴシン, $\mathrm{C}_{16}$-ジヒ ドロスフィンゴシン, $C_{17}$-スフィンゴシン, $C_{18}$-ジヒド ロスフィンゴシン，および多分 17 -メチル $-\mathrm{C}_{18}$-スフィン ゴシンの 7 種が検出された。 そのらち， $C_{18}$ スフィンゴ シンと $C_{16}$-スフィンブシンが全塩基の過半を卢めてい た。

(1) Y.Fujino, S. Yamabuki, T. Negishi and S. Ito: Jap. J. Zootech. Sci., 39, 481 (1968).

(2) F.E. Kurtz: "Fundamentals of Dairy Chemistry", ed. by B. H. Webb and A. H. Johnson, The Avi Publishing Company Inc., Westport, Connecticut, 1965, pp. 91 169.

（3）佐々木林治郎, 津郷友吉：乳の化学, 地球出版, 1962 , p. $35 \sim 38$.

(4) J.Folch, M. Lees and G. H. Sloane Stanley: J. Biol. Chem., 226, 497 (1957).

(5) E. J. King : Biochem. J., 26, 292 (1932).

(6) R. M. C. Dawson : Biochem. J., 75, 45 (1960).

(7) R.C. Gaver and C.C.Sweeley : J. Am. Oil Chemists' Soc., 42, 294 (1965).

(8) K. Karlsson: Nature., 188, 312 (1960).

(9) H. E. Carter and R.C. Gaver : J. Lipid Res., 8, 391 (1967).

(10) S. Gatt and M. M. Rapport : Biochem. J., 101, 680 (1966).

(11) C. C. Sweeley and E. A. Moscatelli : J. Lipid Res., 1, 40 (1959).

(12) H. E. Carter and C. B. Hirschberg : Biochemistry, 7, 2296 (1968).

(13) Y.Fujino and T. Negishi : Nature, 184, 817 (1959). 
（14）伊藤精亮，藤野安彦，根岸 蒂広童産大学 学術研究報告，5，89(1967).

(15) 藤野安彦: 農化, 12, 767 (1956).

(16) C. J. Lauter and E. G. Trams : J. Lipid Res., 3, 136 (1962).

(17) D. Glick : J. Biol. Chem., 156, 643 (1944).

(18) C. Michalec: J. Chromatog., 20, 594 (1965).

(19) W. R. Morrison, E. L. Jack and L. M. Smith : J. Am. Oil Chemists' Soc., 42, 1142 (1965).

(20) H. T. Badings : Neth. Milk and Dairy J., 16, 217 (1962).

(21) L. M. Smith and R. R. Lowry : J. Dairy Sci.,
45, 581 (1962).

（22）森，士肥 造，三影和蜼：日音会報， 38 , 277 (1967).

(23) H. E. Carter and R. C. Gaver: Biochem. Biophys. Res. Commun., 29, 886 (1967).

(24) W. R. Morrison and L. M. Smith : Lipids, 2, 178 (1967).

(25) W. R. Morrison: Lipids, 3, 107 (1968).

(26) C. Michalec: Naturwiss., 53, 254 (1966).

(27) K. Karlsson : Acta Chim. Scand, 18, 2395 (1964). 